\title{
A Global Fight against COVID-19 (Coronavirus) Infection
}

\section{Maithili A Athavale*}

Cancer Biology Lab, Sathgen Biotech-A Unit of Godavari Biorefineries Ltd., Navi Mumbai, India

*Corresponding Author: Maithili A Athavale, Senior Manager (R\&D), Cancer Biology Lab, Sathgen Biotech-A Unit of Godavari Biorefineries Ltd., Navi Mumbai, India.
Received: April 30, 2020

Published: May 05, 2020

(C) All rights are reserved by Maithili A

Athavale.
COVID-19 (Coronavirus) infection has become a burning global health issue today. WHO has declared COVID-19 outbreak as a pandemic and a public health emergency of international concern.

Let us clarify some of the queries regarding this current infection.

What are coronaviruses and what is COVID-19?

Coronaviruses are a large group of RNA viruses and scientists have identified hundreds of such viruses to date. They are named Corona (means crown) because their membranes are studded with spike-like proteins which look like a crown under microscope. Coronaviruses are mostly responsible for causing common cold in humans.

COVID-19 is the infection caused by a newly detected (novel) coronavirus in 2019.

What are the symptoms of COVID-19 infection?

People with COVID-19 infection will develop mild to severe illness. These symptoms may appear from 2 - 14 days after exposure to virus. Common symptoms include fever, cough and difficulty in breathing.

Who are at risk of COVID-19 infection?

Children (as their immunity is not fully developed), older people (as their immunity is declined, pregnant woman and people with underlying health conditions such as diabetes, hypertension, cancer or any other immunocompromised condition are more prone to infection. So, the best defense is to keep ourselves fit and healthy.

What are the different methods available to detect COVID-19 infection?

There are basically two types of methods/kits which detect COVID-19 infection. One is the direct method PCR(Polymerase Chain Reaction) based kit which detects infection (i.e. presence of virus) in patients sample taken by swabbing the nasal passages or throat and the other type is the indirect method which uses the rapid detection kit that detects IgM/IgG (antibodies) in patient's blood sample.

What are IgM/IgG antibodies and what do they indicate?

Body makes different antibodies or immunoglobulins to fight against infection. IgM is the first antibody the body makes when it fights a new infection and after certain period (few days to weeks) IgG antibody is generated and replaces IgM. Thus only presence of IgM indicates most recent infection and presence of IgG without IgM suggest that the infection happened weeks to months in past and will also indicate if a person is immune to the virus.

\section{How can we prevent COVID-19 infection?}

As the saying goes "Prevention is better than cure" it is utmost necessary for everyone to take precautionary measures like following social distancing, using sanitizers, face masks or PPE (Personal protective Equipment) whenever necessary. Our Medical, Paramedical personnel's, Health care workers, Social and Security forces are burning midnight oil to control the situation. Even our company (Godavari Biorefineries Ltd., Somaiya Group) took initiative in manufacturing of sanitizer (named PAAVAN) in view of the need of the society. Also, special facility is created in our hospital for treating COVID-19 patients and our college and hostel rooms are provided for quarantine facility.

In-short, follow the rules, stay safe, stay home and most important is increase your immunity as it's the time for "Survival of the fittest". Finally, in the battle against virus it will be victory of mankind.

Despite all the darkness there is light at the end of the tunnel.

\section{Assets from publication with us}

- Prompt Acknowledgement after receiving the article

- Thorough Double blinded peer review

- Rapid Publication

- Issue of Publication Certificate

- High visibility of your Published work

Website: https://www.actascientific.com/

Submit Article: https://www.actascientific.com/submission.php Email us: editor@actascientific.com

Contact us: +919182824667 